\title{
Effects of amino acid analogues on protein synthesis and degradation in isolated cells
}

\author{
By S. E. KNOWLES AND F. J. BALLARD \\ CSIRO Division of Human Nutrition, Kintore Avenue, Adelaide, \\ South Australia 5000, Australia
}

(Received 28 November 1977 - Accepted 23 January 1978)

\begin{abstract}
I. Naturally-occurring and synthetic analogues of phenylalanine, tyrosine, histidine, arginine, proline, tryptophan and the sulphur amino acids have been tested in rat reticulocytes and in the Reuber $\mathrm{H}_{35}$ hepatoma for effects on protein synthesis and protein degradation and on the heat lability of phosphoenolpyruvate carboxykinase (EC 4.1.1.32) in the hepatoma cells. The experiments were designed to test whether the analogues could be incorporated into mammalian proteins and whether the resultant proteins would be degraded at an accelerated rate.

2. Several analogues, including thiazolylalanine, triazolalanine and selenocystine both stimulated protein synthesis and produced labile protein in reticulocytes. Other analogues, such as dihydroxyphenylalanine, thioproline and pipecolic acid accelerated protein breakdown but probably indirectly via an inhibition of protein synthesis. Azetidine-2-carboxylic acid had the largest effect on protein breakdown in reticulocytes.

3. Labile protein was produced in hepatoma cells incubated in the presence of azetidine-2-carboxylic acid, canavanine, indospicine, triazolalanine, 2-, 3- and 4-fluorophenylalanine. These same analogues, together with 3,4-dehydroproline, $\beta$-2-thienylalanine, dihydroxyphenylalanine, histidinol, 5 - and 6-fluorotryptophan, selenocystine and selenomethionine produced heat-labile phosphoenolpyruvate carboxykinase. Enzyme induced in the presence of selenomethionine or indospicine showed the largest increases in heat lability, and for these analogues equimolar concentrations of methionine and arginine respectively were needed to nullify the enzyme abnormality.

4. The toxicity of the same naturally-occurring analogues has been discussed in terms of their ability to be incorporated into cell proteins.
\end{abstract}

Although only twenty amino acids are found as normal constituents of protein, an additional hundred or more occur in nature often localized to plants or micro-organisms (Fowden, Lewis \& Tristram, 1967; Fowden, 1974; Bell, 1976). These non-protein amino acids are sometimes present in very large amounts, but more usually they are metabolic intermediates in the various organisms and are only found in trace concentrations. Whereas many of these amino acids occur as free compounds, others are found in peptide linkage as part of larger molecules such as antibiotics. Because of the diversity not only in the types of uncommon amino acids but also in their distribution and function, it is hardly surprising that they produce a range of metabolic abnormalities and sometimes toxic effects if they are eaten by mammals. Examples include inhibition of amino acid transport and protein synthesis as well as increases in protein degradation. Other effects seem unrelated to protein metabolism (Fowden et al. 1967; Fowden, 1974).

One way in which the uncommon amino acids can produce toxic symptoms in an animal is by incorporation into enzymes or other body proteins. This occurs because some of the amino acids are sufficiently close analogues of the normal protein amino acids to act as substrates for the $t \mathrm{RNA}$-acylating enzymes involved in protein synthesis. Once a 'wrong' amino acid has been 'activated' to form an aminoacyl-tRNA, there is no selection process in the subsequent reactions of protein synthesis that will prevent the amino acid from being incorporated into protein. However, cells contain a type of 'proof-reading' process by which proteins modified by inclusion of some analogue amino acids may be detected and 
rapidly degraded by proteolysis (Goldberg \& Dice, 1974; Knowles, Gunn, Hanson \& Ballard, I975; Knowles, Gunn, Reshef, Hanson \& Ballard, I975).

In the present paper we have used mammalian cells in culture to test a range of naturallyoccurring and synthetic amino acids for their ability to be incorporated into protein and to produce unstable proteins. We find that several of the analogues tested have marked effects on cell metabolism which are potentially toxic.

\section{EXPERIMENTAL}

\section{Materials}

Normal and analogue amino acids were obtained from the Sigma Chemical Co., St Louis, Mo., USA, or Calbiochem (Australia), Sydney, Australia, with the exception of L-indospicine, which was a gift from Dr M. P. Hegarty, CSIRO Division of Tropical Pastures, Brisbane, Australia. L- $\left[{ }^{3} \mathrm{H}\right]$ leucine (specific radioactivity $50-60 \mathrm{Ci} / \mathrm{mmol}$ ) was from the Radiochemical Centre, Amersham, Bucks., UK, while DL-[guanidino- ${ }^{14} \mathrm{C}$ ]canavanine was from Schwarz/Mann, Orangeburg, New York, NY, USA. NCS Solublizer was obtained from Amersham/Searle Corp., Arlington Heights, Ill., USA.

\section{Measurement of protein synthesis in reticulocytes}

Rats $(200 \mathrm{~g})$ were made anaemic by five daily subcutaneous injections of $6 \mathrm{mg}$ neutralized phenylhydrazine hydrochloride. The animals were left for $2 \mathrm{~d}$, after which approximately $6 \mathrm{ml}$ blood was obtained from the vena cava in heparinized syringes. Reticulocytes were isolated by centrifugation at $1000 \mathrm{~g}$ for $5 \mathrm{~min}$ and then washed twice by suspension and centrifugation. The washing solution contained: $0.145 \mathrm{M}-\mathrm{NaCl}, 5 \mathrm{mM}-\mathrm{KCl}, 1 \cdot 5 \mathrm{~mm}-\mathrm{MgCl}_{2}$. $6 \mathrm{H}_{2} \mathrm{O}, 2$ mM-N-Tris-(hydroxymethyl)methyl-2-aminoethanesulphonic acid (TES), and was adjusted to $\mathrm{pH} 7.5$ with sodium hydroxide. At least $80 \%$ of the blood cells obtained by this procedure were reticulocytes.

Washed reticulocytes from $6 \mathrm{ml}$ blood were incubated at $37^{\circ}$ for $30 \mathrm{~min}$ in $12 \mathrm{ml}$ of a solution containing: $0.12 \mathrm{M}-\mathrm{NaCl}, 5 \mathrm{mM}-\mathrm{KCl}, \mathrm{I} .5 \mathrm{mM}-\mathrm{MgCl}_{2} .6 \mathrm{H}_{2} \mathrm{O}, 20 \mathrm{mM}-\mathrm{TES}, 0.2 \mathrm{~mm}-$ ferrous ammonium sulphate, $5.5 \mathrm{~mm}$-glucose, $60 \mathrm{mg}$ penicillin/l, $100 \mathrm{mg}$ streptomycin $/ 1$ and the following amino acids at the concentrations indicated: $0.45 \mathrm{~mm}$-arginine, $0.15 \mathrm{~mm}$ histidine, $0.6 \mathrm{~mm}$-lysine, $0.25 \mathrm{~mm}$-leucine, $0.17 \mathrm{~mm}$-isoleucine, $0.15 \mathrm{~mm}$-methionine, $0.15 \mathrm{~mm}$ phenylalanine, $0.32 \mathrm{~mm}$ threonine, $0.1 \mathrm{~mm}$-tryptophan, $0.4 \mathrm{~mm}$-valine, $0.21 \mathrm{~mm}$-tyrosine, 0. I mM-cystine, I. $24 \mathrm{~mm}$-alanine, $0.2 \mathrm{~mm}$-asparagine, $0 . \mathrm{I} \mathrm{mm}$-aspartic acid, $0.15 \mathrm{~mm}$-glutamic acid, I.08 mM-proline, $0.75 \mathrm{~mm}$-serine, $0.94 \mathrm{~mm}$-glycine, I. $19 \mathrm{~mm}$-glutamine, $0.2 \mathrm{mM}-$ cysteine. The concentrations of amino acids are twice those measured in serum from rats in the CSIRO Divisional colony, although additional amounts of tryptophan and cysteine were included to ensure that these were not limiting. The normal amino acid to which an analogue was being compared was omitted from the mixture. After pre-incubation, reticulocytes from $0.25 \mathrm{ml}$ blood were pelleted and resuspended in $2 \mathrm{ml}$ of a similar medium but with the analogue added, usually at $2 \mathrm{mM}$, together with $3 \mu \mathrm{Ci}\left[{ }^{3} \mathrm{H}\right]$ leucine and $15 \mathrm{nmol}$ non-radioactive leucine $/ \mathrm{ml}$. Incubation was caried out for $30 \mathrm{~min}$ at $37^{\circ}$, after which the cells were washed twice by suspension in the same washing solution as used for isolation of reticulocytes. Finally the cells were suspended in the medium used for pre-incubation but with leucine added at $2 \mathrm{mM}$ and cycloheximide at $10 \mu_{\mathrm{M}}$, to minimize reincorporation of isotope during subsequent degradation measurements. Samples of the cell suspension $(50 \mu \mathrm{l})$ were added to $100 \mu \mathrm{l}$ of trichloroacetic acid ( $100 \mathrm{~g} / \mathrm{l})$, centrifuged at $3000 \mathrm{~g}$ for $5 \mathrm{~min}$ and radioactivity measured in the protein pellet as described by Knowles, Gunn, Hanson et al. (1975). 


\section{Measurement of protein degradation in reticulocytes}

Protein was labelled in reticulocytes as described in the previous section. The final cell suspension was incubated at $37^{\circ}$ with $50 \mu$ l samples being taken at various times for the measurement of trichloroacetic acid-soluble and trichloroacetic acid-insoluble radioactivity (Knowles, Gunn, Hanson et al. 1975). Protein breakdown was calculated as the percentage amount degraded, according to the expression:

$$
\text { protein degradation }=100 \times \frac{\text { trichloroacetic acid-soluble radioactivity }}{\text { total radioactivity }} .
$$

Values for this at zero time were subtracted from the measurements at different time intervals during the degradation period.

\section{Degradation of protein in hepatoma cells}

Reuber $\mathrm{H}_{35}$ hepatoma cells were grown in monolayer culture as described by Knowles, Gunn, Hanson et al. (1975). The cell protein was labelled for $3 \mathrm{~h}$ with $\left[{ }^{3} \mathrm{H}\right]$ leucine in the presence of each amino acid analogue, usually at $2 \mathrm{~mm}$, in Eagle's minimal essential medium (Eagle, 1959) but with the relevant normal amino acid omitted. Degradation of ${ }^{3} \mathrm{H}$-labelled protein was measured as described by Knowles, Gunn, Hanson et al. (I975). In some experiments protein was labelled with $\left[{ }^{14} \mathrm{C}\right]$ canavanine instead of $\left[{ }^{3} \mathrm{H}\right]$ leucine.

\section{Heat lability of phosphoenolpyruvate carboxykinase (EC 4.I.I.32; PEPCK)}

PEPCK was induced in hepatoma cells during a $16 \mathrm{~h}$ incubation in Eagle's minimal essential medium containing $0.5 \mathrm{~mm}$-dibutyryl cyclic-AMP, I mM-theophylline and $5 \mu \mathrm{M}$-dexamethasone, with the relevant amino acid omitted and with the analogue added, usually at a concentration of $2 \mathrm{mM}$. The cells were harvested, lysed, a cytosol extract was prepared and heat-lability measured at $42^{\circ}$ as described by Knowles, Gunn, Reshef et al. (1975). The specific activity of the enzyme was expressed as m-units of catalytic acitivity (nmol substrate converted per min at $37^{\circ}$, Ballard \& Hanson, 1969) per mg extracted protein (Lowry, Rosebrough, Farr \& Randall, I95I).

\section{Arginase (EC 3.5.3.1) assay}

Arginase was measured in liver and hepatoma extracts as described by Schimke (1970). One unit of activity catalyses the formation of I $\mu \mathrm{mol}$ urea per min at $37^{\circ}$.

\section{RESULTS}

\section{Protein synthesis and degradation in reticulocytes}

Reticulocytes have several advantages over other mammalian cells for the detection of abnormal proteins. Thus they can be incubated under conditions very similar to those occurring in vivo, they have a rapid rate of protein synthesis, and essentially all the protein synthesized is haemoglobin which normally has an extremely long half-life. This last point should simplify the detection of any abnormal protein that has been synthesized in the presence of an amino acid analogue. Furthermore, the high rate of protein synthesis in reticulocytes necessitates only a brief labelling period so that any unstable protein formed will not have been degraded before commencing the degradation measurement.

The time-course of degradation of normal reticulocyte protein is shown in Fig. I, together with experiments on some analogues of phenylalanine and tyrosine. Normal protein synthesized in a complete medium was not completely stable but contained a small fraction of a labile form. However, the remaining protein remained stable even if the reticulocytes were 


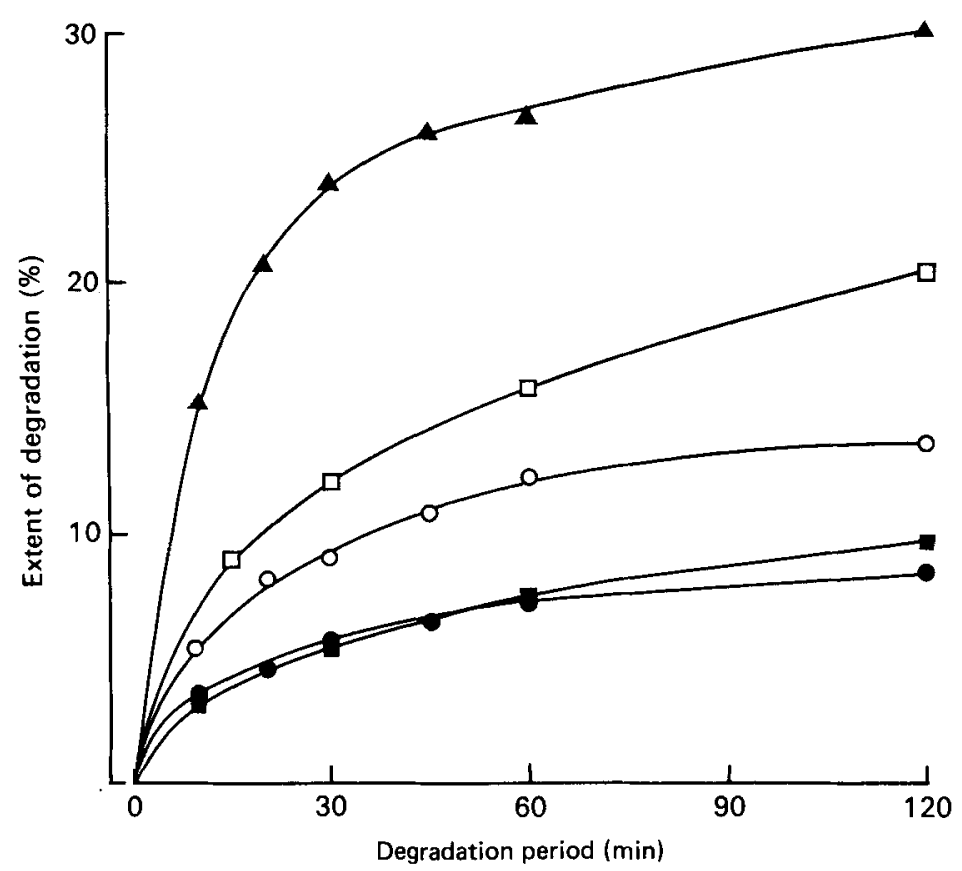

Fig. 1. Degradation (\%) of ${ }^{3} \mathrm{H}$-labelled protein in reticulocytes. For details of protein labelling and the measurement of degradation, see p. 277. Degradation curves are presented for protein synthesized in the presence of: $(\odot)$, all amino acids; $(O)$, all amino acids except for phenylalanine (phe) and tyrosine (tyr); ( $\square$ ), all amino acids except for phe and tyr, $5 \mathrm{~mm}$-mimosine added; $(\square)$, all amino acids except for phe and tyr, $5 \mathrm{mM}$-L-dihydroxyphenylalanine added; $(\Delta)$, all amino acids except for phe and tyr, 5 mm-thiazolylalanine added. Protein synthesis, expressed as the percentage amount of that occurring in the absence of phe and tyr, was: mimosine, 107; dihydroxyphenylalanine, 47; thiazolylalanine, 140 .

incubated for up to $6 \mathrm{~h}$. A somewhat different pattern of protein degradation was found when a single amino acid was omitted from the labelling medium, even in the absence of an analogue. Under these conditions a greater fraction of labile protein was present, a situation which necessitated two control incubations for each analogue being tested, because an increase in degradation from that found in complete medium to that found in the deficient control (with a single amino acid omitted) did not necessarily imply the incorporation of analogue. This was especially true if an analogue inhibited protein synthesis to the same extent as omission of the normal amino acid.

The three analogues shown in Fig. $\mathrm{I}$ produce different responses. Mimosine had no effect on synthesis compared to the 'minus tyrosine, phenylalanine' control (the deficient control), while the protein formed in its presence was no less stable than either control. L-dihydroxyphenylalanine inhibited protein synthesis markedly and produced labile proteins. However, this effect can be interpreted as an extreme instance of the deficient control rather than evidence for substitution in haemoglobin. On the other hand thiazolylalanine both increased protein labelling above the deficient control and increased markedly the rate of protein degradation. Clearly this analogue was an example of one which was incorporated into reticulocyte protein to form abnormal protein.

The largest effect on degradation in reticulocytes was seen with azetidine-2-carboxylic acid (Fig. 2). At a concentration of $10 \mathrm{~mm}$ approximately $70 \%$ of the proteins labelled in the presence of the analogue had a half-life of $15 \mathrm{~min}$. The amount of labile protein formed was dependent on the concentration of azetidine-2-carboxylic acid, but even at $0.5 \mathrm{~mm}$ in 


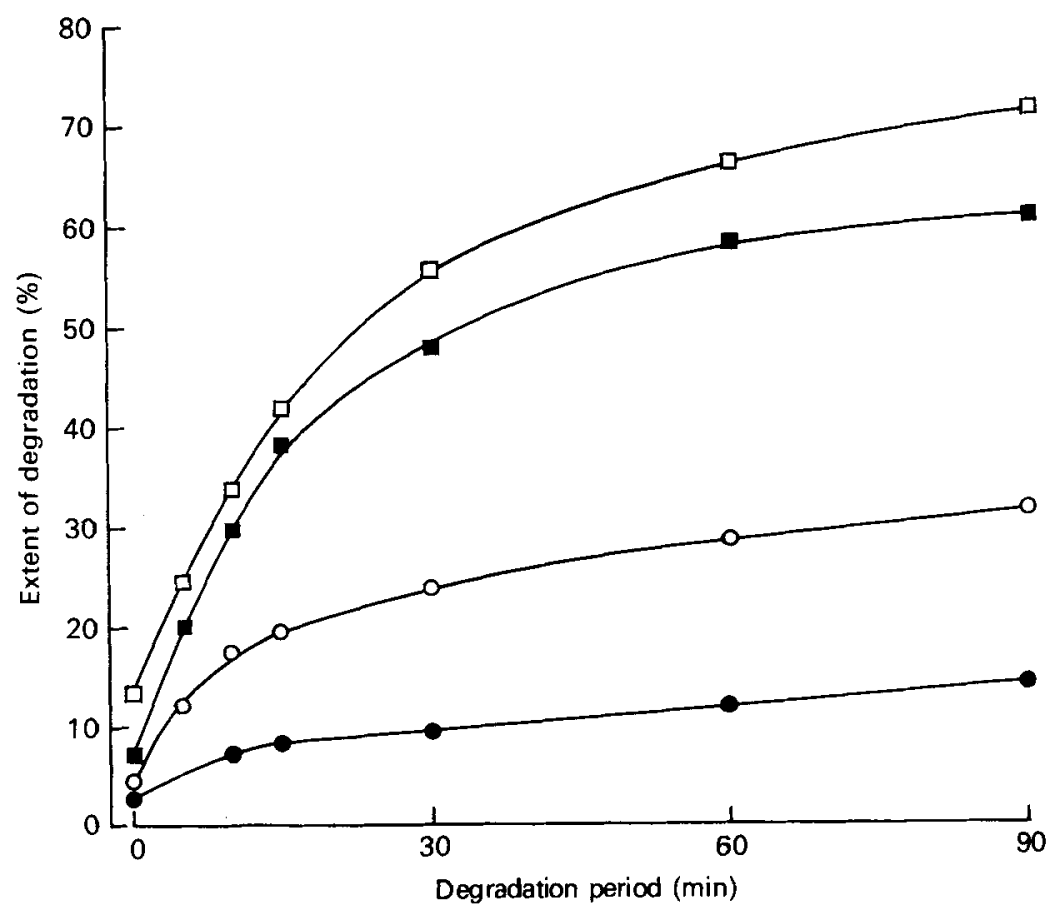

Fig. 2. Degradation (\%) of ${ }^{3} \mathrm{H}$-labelled protein was measured in reticulocytes after labelling of protein in an alanine-free medium, with the following additions: $(0)$, none; $(O), 0.5$ mm-azetidine2-carboxylic acid; (四), 2.5 mm-acetidine-2-carboxylic acid; ( $\square$ ), 10 mM-azetidine-2-carboxylic acid. For details, see p. 277.

the labelling medium approximately $30 \%$ of the resultant protein was labile. Further investigations on the effects of azetidine-2-carboxylic acid have shown it to be an analogue of alanine in reticulocytes. Thus alanine competed with azetidine-2-carboxylic acid even when the analogue concentration was over Ioo-fold higher than alanine (Table I). This result was surprising since azetidine-2-carboxylic acid is a lower homologue of proline, with a four-membered rather than a five-membered ring structure. Yet extremely high proline concentrations were needed to reduce the azetidine-2-carboxylic acid effect, and then only when the analogue concentration was reduced to low levels.

The effects of proline, phenylalanine-tyrosine, histidine, tryptophan, arginine and selenium analogues on protein synthesis and degradation in reticulocytes are listed in Table 2 . Several types of effects can be seen. First, analogues such as thiazolylalanine, triazolalanine and selenocystine increased protein synthesis above the deficient control and also stimulated protein degradation. As mentioned previously, these analogues must surely be incorporated into protein in order to explain the effects. The argument for azetidine-2-carboxylic acid incorporation was less convincing since protein labelling was not increased. Secondly, analogues such as the fluorophenylalanines and the fluorotryptophans increased protein labelling but did not produce labile protein. Again this effect is explained by actual incorporation of each analogue, but to form protein which cannot be recognized as modified by the proteolytic system of the cell. Thirdly, there are a group of analogues which depress protein synthesis and yield unstable protein. The most reasonable explanation for this response is that the analogue has some inhibitory action on $t$ RNA acylation, or another step in protein synthesis, with the accelerated degradation being a consequence of this inhibition rather than an indication of analogue incorporation. The effect is thus comparable 
Table I. Competition in reticulocytes between azetidine-2-carboxylic acid $(A 2 C)$ and alanine (ala)

(Degradation of $\left[{ }^{3} \mathrm{H}\right]$ protein in reticulocytes was followed after labelling in the presence of complete medium with the modifications indicated. Unless noted otherwise, proline (pro), ala and (A2C were present at concentrations of $1.1 \mathrm{~mm}, 1.25 \mathrm{~mm}$ and $2.5 \mathrm{~mm}$ respectively)

\begin{tabular}{llc} 
Omissions & \multicolumn{1}{c}{ Additions } & $\begin{array}{c}\text { Protein } \\
\text { degraded } \\
(\% \text { in I h })\end{array}$ \\
None & None & 3.9 \\
Pro, ala & None & $3 \cdot 6$ \\
None & A2C & $4 \cdot 3$ \\
Pro, ala & A2C & $41 \cdot 3$ \\
Pro, ala & A2C, pro $0.5 \mathrm{mM}$ & $46 \cdot \mathrm{I}$ \\
Pro, ala & A2C, pro $2 \cdot 5 \mathrm{mM}$ & $65 \cdot 5$ \\
Pro & A2C & $5 \cdot 9$ \\
Ala & A2C & $40 \cdot 7$ \\
Ala & A2C, ala Io $\mu \mathrm{M}$ & $29 \cdot 9$ \\
Ala & A2C, ala $50 \mu \mathrm{M}$ & $11 \cdot 9$
\end{tabular}

Table 2. Effects of various amino acids on protein synthesis and subsequent degradation in reticulocytes

(The effect of each analogue tested on protein synthesis and protein degradation has been assessed according to the scale: -- , large inhibition; - , inhibition; 0 , no effect; + , activation; ++ , large activation. Details of the assays are given in the text)

Analogue

L-thioproline

4-Hydroxy-L-proline

L-pipecolic acid

5-Hydroxy-L-pipecolic acid

3,4-Dehydro-L-proline

L-mimosine

$\beta$-2-Thienyl-DL-alanine

DL-2-fluorophenylalanine

DL-3-fluorophenylalanine

DL-4-fluorophenylalanine

DL-4-aminophenylalanine

DL- $\alpha$-aminophenylacetic acid

2-Thiazolyl-pL-alanine

L-dihydroxyphenylalanine

L-canavanine

L-indospicine

L-homoarginine

L-histidinol

DL-1,2,4-triazol-3-alanine

L-I-methylhistidine

L-3-methylhistidine

DL-5-fluorotryptophan

DL-6-fluorotryptophan

DL-7-azatryptophan

DL-5-methyltryptophan

L-azetidine-2-carboxylic acid

Seleno-DL-cystine

Seleno-DL-methionine

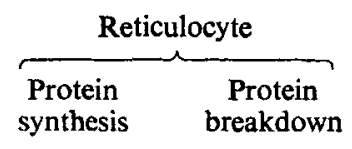

$\begin{array}{cc}-- & + \\ 0 & 0 \\ 0 & 0 \\ - & + \\ 0 & 0 \\ 0 & 0 \\ + & 0 \\ + & 0 \\ + & 0 \\ + & 0 \\ 0 & 0 \\ 0 & 0 \\ + & ++ \\ - & + \\ + & 0 \\ 0 & 0 \\ + & - \\ - & + \\ ++ & + \\ 0 & 0 \\ 0 & 0 \\ + & 0 \\ + & 0 \\ + & 0 \\ + & 0 \\ 0 & ++ \\ + & + \\ ++ & 0\end{array}$




\section{Table 3. Degradation of abnormal protein in hepatoma cells*}

(Mean values with their standard errors)

\begin{tabular}{|c|c|c|}
\hline \multirow[b]{2}{*}{ Amino acids added } & \multicolumn{2}{|c|}{ Degradation rate-constant $(/ \mathrm{h})$} \\
\hline & Mean & SE \\
\hline \multicolumn{3}{|c|}{ Protein labelled with $\left[{ }^{8} \mathrm{H}\right]$ leucine } \\
\hline None & $-0.05 \mathrm{I}$ & 0.004 \\
\hline Arginine $2 \mathrm{~mm}$ & -0.047 & 0.001 \\
\hline Canavanine $2 \mathrm{~mm}$ & -0.122 & 0.005 \\
\hline Indospicine $2 \mathrm{~mm}$ & -0.090 & 0.004 \\
\hline \multicolumn{3}{|c|}{ Protein labelled with $\left[{ }^{14} \mathrm{C}\right.$ canavanine } \\
\hline None & -0.050 & 0.004 \\
\hline Canavanine $0.1 \mathrm{mM}$ & -0.085 & 0.011 \\
\hline Canavanine $0.5 \mathrm{~mm}$ & -0.086 & 0.014 \\
\hline
\end{tabular}

* For details of protein degradation measurements with either $\left[{ }^{3} \mathrm{H}\right]$ leucine or $\left[{ }^{14} \mathrm{C}\right]$ canavanine, see p. 277 .

to that shown by the deficient control. A fourth group of analogues did not affect protein synthesis or protein degradation, presumably because the analogues differed too widely from the parent amino acid to act as competitors.

Essentially all the analogues listed in Table 2 were tested at a concentration of $2 \mathrm{mM}$ and in the absence of the relevant, normal amino acid. Degradation rates above those seen in the deficient control cells were not observed at lower concentrations of analogues, except for azetidine-2-carboxylic acid and thiazolylalanine. Accordingly, the reticulocyte system was relatively insensitive to most of the analogues.

\section{Protein degradation and heat lability of PEPCK in Reuber hepatoma cells}

Hepatoma cells offer an alternative assay to reticulocytes for the effects of analogue amino acids on protein synthesis and degradation. Differences might have been expected not only because the hepatoma is a rapidly-dividing monolayer, but also because a wide range of proteins are being synthesized rather than a preponderance of a single protein. In addition, the long-term viability of the cells enables PEPCK to be induced over a $16 \mathrm{~h}$ period in the presence of analogues. Since the half-life of this enzyme is approximately $5 \mathrm{~h}$ in the hepatoma line (Knowles, Gunn, Reshef et al. 1975), any residual normal enzyme would be a very small proportion of total activity after the $16 \mathrm{~h}$ incubation in the presence of analogue. Further, inducing conditions during this period increased the enzyme activity by approximately 4-fold, so that virtually all the enzyme present after induction would have been formed while the analogue was included in the medium. Because of these factors, lability of PEPCK could be a very sensitive assay for analogue effects. Although it would be preferable to measure enzyme degradation in the intact hepatoma cell rather than heat lability in cell extracts, the simplicity of the latter measurement was an advantage.

Total protein in the hepatoma cells has a degradation rate-constant of $-0.05 / \mathrm{h}$, which represents an average half-life of approximately $14 \mathrm{~h}$ (Table 3 ). The arginine analogues canavanine and indospicine increased the degradation rate-constant by $2-3$-fold when they are added at a $2 \mathrm{~mm}$ concentration (Table 3 ). Since $\left[{ }^{14} \mathrm{C}\right]$ canavanine can be used as an alternative to $\left[{ }^{3} \mathrm{H}\right]$ leucine for labelling canavanyl-protein, this labelled analogue could be useful in degradation studies. However, the trace amounts of $\left[{ }^{14} \mathrm{C}\right]$ canavanine needed for labelling studies did not produce labile enzyme (Table 3), implying perhaps the need for several canavanine molecules to be inserted in each protein chain. Such multiple incorporation would only be possible if a substantial proportion of the $t \mathrm{RNA}_{\text {arginine }}$ was charged with canavanine, an unlikely possibility when only trace amounts of $\left[{ }^{14} \mathrm{C}\right]$ canavanine were used. 


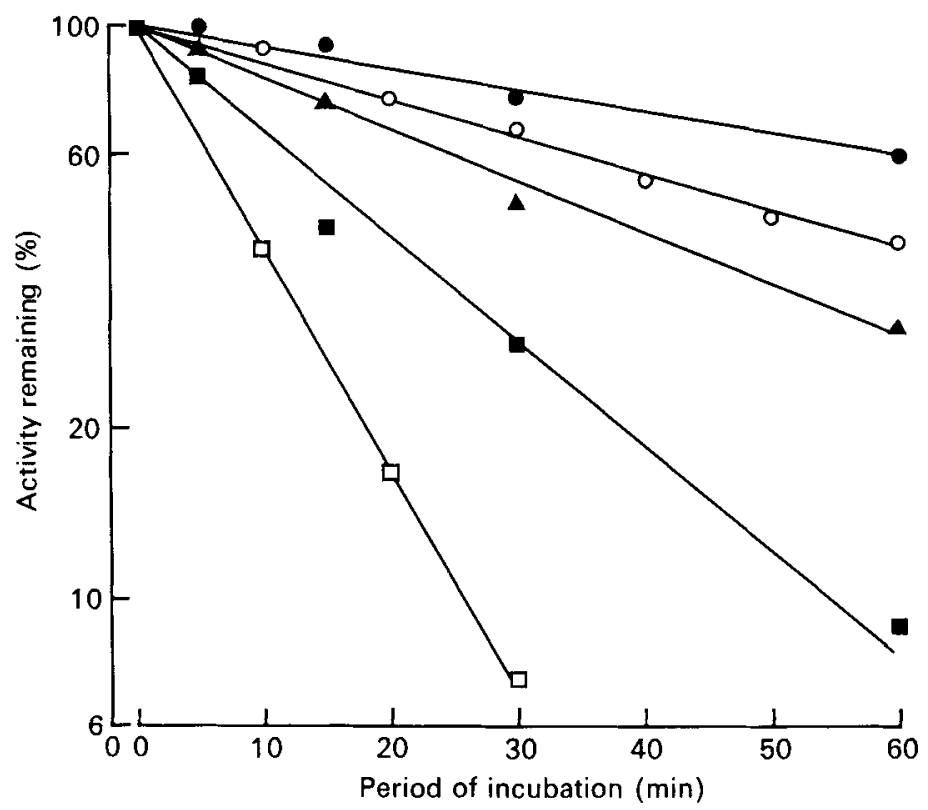

Fig. 3. Inactivation (activity remaining $(\%)$ ) of phosphoenolpyruvate carboxykinase $(E C 4.1$. I . 32) at $42^{\circ}$ in extracts of Reuber hepatoma cells that had been incubated for $16 \mathrm{~h}$ previously in a complete medium except for the omissions and additions indicated: ( $(0), 0.2$ mm-tyrosine (tyr) and phenylalanine (phe) added; (O), $0.2 \mathrm{~mm}$-methionine added; $(\boldsymbol{\Delta})$, tyr and phe omitted, $2 \mathrm{~mm}-2$ fluorophenylalanine added; (目), tyr and phe omitted, $0.2 \mathrm{~mm}-3$-fluorophenylalanine added; ( $\square$ ), methionine omitted, $0.2 \mathrm{~mm}$-selenomethionine added.

Increasing the concentration of unlabelled canavanine added with $\left[{ }^{14} \mathrm{C}\right]$ canavanine did indeed lead to more labile protein, but even at a concentration of $0.5 \mathrm{~mm}$ the degradation rate-constant was lower than if $\left[{ }^{3} \mathrm{H}\right]$ leucine and 2 mM-canavanine had been used. Concentrations of unlabelled canavanine greater than $0.5 \mathrm{~mm}$ could not be tested with $\left[{ }^{14}\right]$ canavanine owing to the marked decrease in isotope incorporation which resulted from the lowered specific radioactivity. The use of labelled analogues does not seem, therefore, to be an advantage over incubations of non-radioactive analogues in the presence of $\left[{ }^{3} \mathrm{H}\right]$ leucine.

PEPCK activity induced in the presence of the phenylalanine anlogues, 2-fluorophenylalanine or 3-fluorophenylalanine was more heat-labile than normal enzyme (Fig. 3). Both analogues reduced the extent of induction of the enzyme, perhaps because heat-labile enzyme had been degraded at an increased rate during the long induction period. Low concentrations of selenomethionine resulted in a very labile enzyme with a half-life in the inactivation assay of $8 \mathrm{~min}$ as compared to $50 \mathrm{~min}$ for the control enzyme. The inactivation curves in Fig. 3 all showed first-order plots of enzyme activity $v$. period of incubation. Although this result is expected whenever the heat inactivation of an enzyme is followed, the presence of a second PEPCK in the hepatoma cells could lead to a biphasic response. Indeed the hepatoma cells do contain a mitochondrial enzyme (Knowles, Gunn, Reshef et al. I 975), which is less heat labile, but since it accounts for only approximately 10\% of the total activity, its contribution to the heat-lability test would be minor provided that inactivation was not followed to extremely low enzyme activities. Accordingly, a temperature was chosen for the inactivation experiments at which the normal enzyme was relatively stable.

The amino acids tested for their effects on hepatoma cells are listed in Table 4 . Using the classifications of effects listed previously for reticulocyte protein synthesis and degradation, only triazolalanine stimulated both protein synthesis and degradation, although the fluoro- 
Table 4. Effects of amino acid analogues on protein synthesis, protein degradation and phosphoenolpyruvate carboxykinase (EC 4. I I .32) heat lability in Reuber hepatoma cells*

(The effect of each analogue on protein synthesis, protein degradation and enzyme lability has been assessed according to the scale: $--;$ large inhibition; - , inhibition; 0 , no effect; + , activation; ++ , large activation)

\begin{tabular}{|c|c|c|c|}
\hline & \multicolumn{3}{|c|}{ Hepatoma } \\
\hline & $\begin{array}{l}\text { Protein } \\
\text { synthesis }\end{array}$ & $\begin{array}{c}\text { Protein } \\
\text { breakdown }\end{array}$ & $\begin{array}{l}\text { Enzyme } \\
\text { lability }\end{array}$ \\
\hline L-thioproline & 0 & 0 & 0 \\
\hline 4-Hydroxy-L-proline & 0 & 0 & 0 \\
\hline L-pipecolic acid & 0 & 0 & 0 \\
\hline 5-Hydroxy-L-pipecolic acid & 0 & 0 & 0 \\
\hline 3,4-Dehydro-L-proline & 0 & 0 & ++ \\
\hline L-azetidine-2-carboxylic acid & - & ++ & ++ \\
\hline L-mimosine & ND & ND & 0 \\
\hline$\beta$-2-Thienyl-DL-alanine & 0 & 0 & + \\
\hline DL-2-fluorophenylalanine & 0 & + & + \\
\hline DL-3-fluorophenylalanine & 0 & + & ++ \\
\hline DL-4-fluorophenylalanine & 0 & + & ++ \\
\hline DL-4-aminophenylalanine & 0 & 0 & 0 \\
\hline DL- $\alpha$-aminophenylacetic acid & 0 & 0 & 0 \\
\hline 2-Thiazolyl-DL-alanine & 0 & 0 & 0 \\
\hline L-dihydroxyphenylalanine & 0 & 0 & + \\
\hline L-canavanine & 0 & ++ & ++ \\
\hline L-indospicine & 0 & + & ++ \\
\hline L-homoarginine & ND & ND & 0 \\
\hline L-histidinol & -- & 0 & + \\
\hline DL-I,2,4-triazol-3-alanine & + & + & + \\
\hline L-I-methylhistidine & ND & ND & 0 \\
\hline L-3-methylhistidine & ND & ND & 0 \\
\hline DL-5-fluorotryptophan & + & 0 & ++ \\
\hline DL-6-fluorotryptophan & + & 0 & ++ \\
\hline DL-7-azatryptophan & 0 & + & 0 \\
\hline DL-5-methyltryptophan & + & 0 & ND \\
\hline Seleno-DL-cystine & 0 & 0 & ++ \\
\hline Seleno-DL-methionine & 0 & 0 & ++ \\
\hline
\end{tabular}

ND, not determined.

* For details of procedures, see p. 281 .

phenylalanines, together with canavanine, indospicine and azatryptophan accelerated protein degradation without affecting protein synthesis. The fluorotryptophans and methyltryptophan showed evidence of incorporation but did not produce labile protein. Azetidine2-carboxylic acid slightly inhibited protein synthesis but had a large effect on protein breakdown, while histidinol was a powerful inhibitor of protein synthesis without affecting protein lability. Many analogues would be classified in the fourth group as affecting neither protein synthesis nor protein breakdown.

Over half the analogues tested gave rise to heat-labile PEPCK with at least one analogue to each normal amino acid having a large effect on enzyme stability (Table 4). The effect of selenomethionine on enzyme lability has already been shown in Fig. 3. Unstable enzyme was formed when cells were incubated in medium containing this analogue at concentrations greater than $20 \mu \mathrm{M}$ and a maximal response was found at $200 \mu \mathrm{M}$-selenomethionine (Fig. 4). When increasing concentrations of methionine were present in the inducing medium together with $500 \mu \mathrm{M}$-selenomethionine, there was a gradual increase in the heat stability of PEPCK until at equimolar concentrations of methionine and analogue the heat stability was similar 


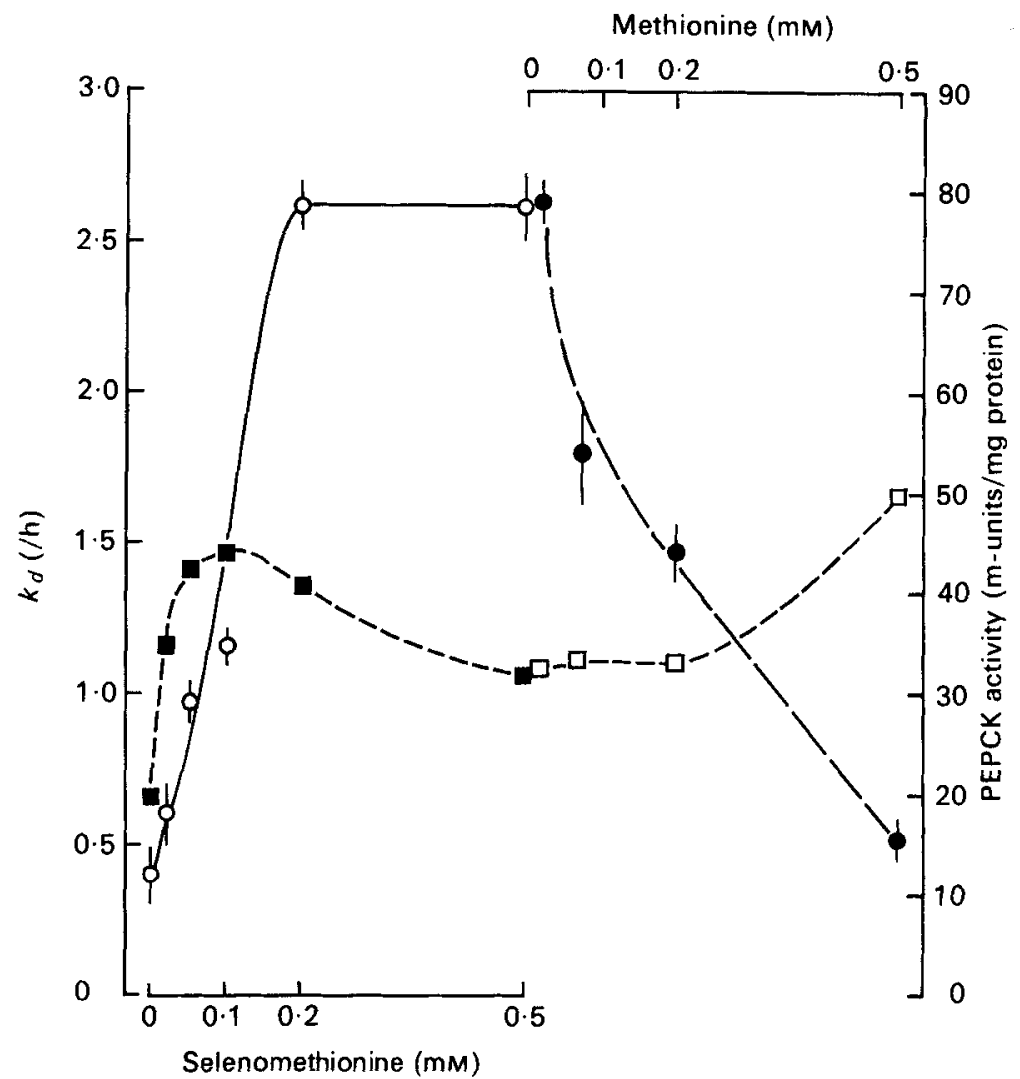

Fig. 4. Effects of selenomethionine and methionine concentrations on the specific activity (m-units/ mg protein) $(\mathbf{\omega}, \square)$ and inactivation rate-constant $\left(k_{d} ; / \mathbf{h}\right)(\mathbf{e}, 0)$ of phosphoenolpyruvate carboxykinase (EC 4.1.I.32; PEPCK). Enzyme was induced in hepatoma cells in the presence of selenomethionine concentrations from 0 to $0.5 \mathrm{~mm}$ in the absence of methionine $(0, \mathbf{a})$, or in the presence of $0.5 \mathrm{~mm}$-selenomethionine and increasing concentrations of methionine $(0, \square)$ before the measurement of heat lability and enzyme specific activity. Values of $k_{d}$ were determined by least squares analysis from five values for 'period of incubation' and represent the slope \pm SE.

to the normal enzyme. Measurements of enzyme specific activity in these experiments showed a large increase above that present in the deficient control even at $20 \mu \mathrm{M}$-selenomethionine. This result argues strongly for the replacement of methionine by the analogue in the induced enzymes. When the analogue concentration was increased beyond $200 \mu \mathrm{M}$, the specific activity decreased, presumably a reflection of a reduced enzyme stability during the induction period (Fig. 4).

Comparable experiments to those described previously have also been carried out with the arginine analogue, indospicine (Fig. 5). Very low concentrations of indospicine gave rise to heat-labile PEPCK. Thus a significant $(P<0.05)$ response was evident at $5 \mu \mathrm{M}$-indospicine, while 2-fold and 4-fold increases in lability were found at concentrations of Io $\mu \mathrm{M}$ and $100 \mu \mathrm{M}$ respectively, Equimolar concentrations of arginine and indospicine prevented the formation of labile enzyme. A marked difference occurred between the specific activity of the enzyme after induction in the presence of indospicine as compared to selenomethionine. With the arginine analogue, PEPCK activity was always lower when heat-labile enzyme was produced. A result of this type probably reflects an increased degradation of the modified enzyme within the hepatoma cells. 


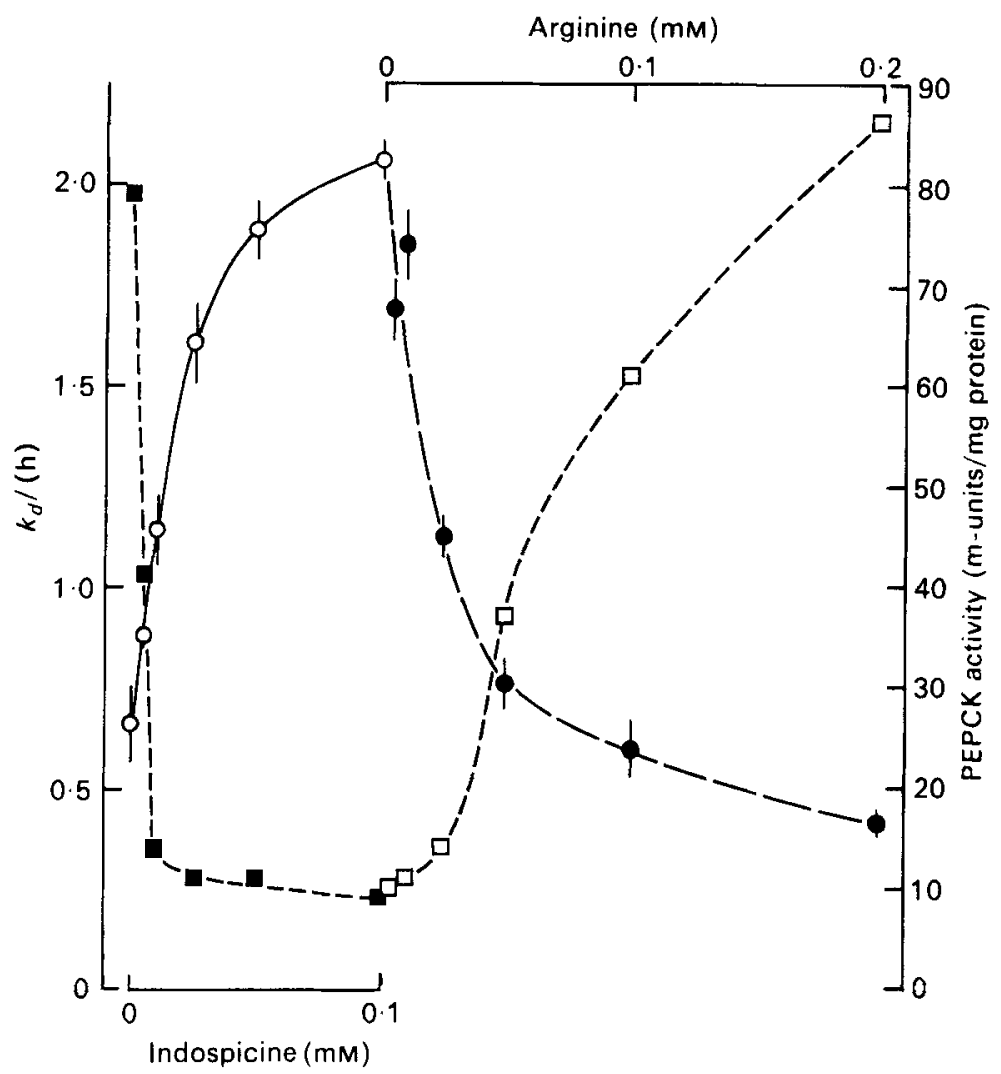

Fig. 5. Effects of indospicine and arginine concentrations on the specific activity (m-units/mg protein $(\square, \square)$ and inactivation rate-constant $\left(k_{i} ; / \mathrm{h}\right)(0,0)$ of phosphoenolpyruvate carboxykinase ( $E C_{4} 4.1 .1 .32$; PEPCK). The enzyme was induced in hepatoma cells either in the presence of indospicine concentrations ranging from 0 to $0.1 \mathrm{mM}(\mathrm{O}, \mathrm{W})$, or in the presence of $0.1 \mathrm{~mm}$ indospicine together with increasing concentrations of arginine $(0, \square)$ before the measurement of heat lability and enzyme specific activity. Values of $k_{d}$ were determined by least squares analysis from five values for 'period of incubation' and represent the slope $\pm \mathrm{SE}$.

Table 5. Substrate specificity and distribution of arginase (EC $3 \cdot 5 \cdot 3.1$ )

(Mean values with their standard errors; enzyme activity, $v$, was measured at a substrate concentration of $25 \mathrm{mM}$ )

$\begin{array}{ccc}\text { Tissue substrate } & \begin{array}{c}v \\ \text { (units } / \mathrm{mg} \text { protein) }\end{array} & \begin{array}{c}K_{\mathrm{m}} \\ (\mathrm{M})\end{array} \\ \begin{array}{ccc}\text { Liver } \\ \text { Arginine }\end{array} & \begin{array}{l}4.28 \pm 0.62 \\ 0.12 \pm 0.02\end{array} & \begin{array}{l}0.005 \\ 0.2\end{array} \\ \begin{array}{c}\text { Canavanine } \\ \text { Indospicine }\end{array} & <0.01 & - \\ \begin{array}{c}\text { Hepatoma } \\ \text { Arginine }\end{array} & 0.15 & -\end{array}$

$K_{\mathrm{m}}$, Michaelis constant 
Indospicine and canavanine are potentially significant analogues to liver tissue because the high activity of arginase in that tissue will keep arginine concentrations very low. To test the significance of this result in the hepatoma line we have compared arginase activity between liver and the hapatoma and also measured the effectiveness of the two analogues as substrates for arginase. As shown in Table 5, the hepatoma cells contained some arginase, but very much less than liver. Canavanine was a poor substrate for arginase, with both a low relative conversion rate and a much higher Michaelis constant. No production of urea from indospicine could be detected.

\section{DISCUSSION}

We have tested a range of analogues to the amino acids proline, phenylalanine, tyrosine, histidine, tryptophan, arginine and the $S$ amino acids for their effects on protein synthesis and degradation. Although toxic actions of the analogues would be most relevant if the screening could be done in whole animals, we have instead used isolated mammalian cells for the purpose. These cells are readily obtained and can be used under carefully-controlled conditions, especially with regard to the concentration of the relevant normal amino acid. Accordingly, each analogue can be tested, not only in the absence of the normal amino acid to which it is structurally related, but also under conditions where the normal amino acid is present at controlled concentrations. With this approach, the effectiveness of each analogue as a competitor or inhibitor can be assessed.

There are three major situations during which competition between analogue and normal amino acid might be expected: (I) when the analogue is present in the diet in large amounts; (2) where the analogue is a good substrate for or inhibitor of protein synthesis; (3) when the intracellular concentration of a particular, normal amino acid is very low. Each of these situations should be considered in any evaluation of the potential toxicity of an analogue.

A number of plant species contain large concentrations of unusual amino acids. Invariably these amino acids are absent from the protein of such species and are present as free amino acids. This occurs as a consequence of modifications to the respective $t$ RNA synthetases in the producer species whereby the analogues are no longer substrates for these enzymes. On the other hand, animals eating the plants will be at risk unless large amounts of the respective, normal amino acids are available. Of the analogues tested in the present experiments, four occur in high concentrations in certain plants. Thus canavanine has a wide distribution amongst leguminosae and in the seed of Dioclea megacarpa comprises $70-100 \mathrm{mg} / \mathrm{g}$ (Bell, I976); azetidine-2-carboxylic acid occurs at slightly lower concentrations in the rhizomes and shoots of Convallaria majalis, Polygonatum multiflorum, as well as in seeds of several legumes (Fowden, 1959); mimosine is present in roots and stems of Mimosae and at up to $100 \mathrm{mg} / \mathrm{g}$ dry weight in leaves, stems and seeds of the legume Leucaena glauca (Hegarty, Court \& Thorne, 1964); dihydroxyphenylalanine occurs at more than $80 \mathrm{mg} / \mathrm{g}$ in the seed of Mucuna mutisiana (Bell \& Janzen, I97I). Analysis of the effects of these analogues on protein synthesis and protein degradation has indicated very different responses. Thus mimosine affects neither protein synthesis nor protein degradation in the two cell types used. Its toxicity is thought to occur via an inhibition of mitosis, a response which probably explains its action as a chemical defleecing agent in sheep (Hegarty, Schinckel \& Court, 1964). Azetidine-2-carboxylic acid is toxic to animals and has been shown to be incorporated into reticulocyte protein (Baum, Johnson, Franzblau \& Troxler, 1975). The abnormal proteins formed could explain the toxicity of the analogue, particularly when the increased demand on protein synthesis caused by labile proteins is taken into account. Similarly, canavanine has been shown to be incorporated into animal cell proteins (Kruse, White, Carter \& McCoy, 1959; Allende \& Allende, 1964), consistent with the effects noted in the hepatoma cells. Dihydroxyphenylalanine is not thought to be incorporated into protein but 
acts as a precursor of biogenic amines (Fowden et al. 1967). However, the analogue increased the heat lability of PEPCK, a property which is difficult to explain other than via its incorporation into the enzyme.

Both canavanine and azetidine-2-carboxylic acid can be incorporated into proteins because they are substrates for $t$ RNA-acylating enzymes (Fowden et al. 1967; Fowden, 1974). In addition to these two analogues, the fluorine-substituted derivatives of phenylalanine and tryptophan appear to be incorporated into reticulocyte protein and into PEPCK. These analogues, together with thiazolylalanine and triazolalanine, do not occur naturally (Fowden et al. 1967) and would not be expected to have any nutritional importance. On the other hand selenomethionine and selenocystine could be formed if Se was present in the diet in relatively large amounts. The toxic effects of plants grown on seleniferous soils is possibly explained by the formation of abnormal proteins containing the selenoamino acids in animal cells.

The third situation where competition between analogue and normal amino acid occurs is those unusual instances where the normal amino acid is present in very low amounts. Although this could theoretically occur on unusual diets, it is almost impossible in practice unless the only amino acid source was a protein with a very marked deficiency in an amino acid. On the other hand, mammalian liver maintains extremely low arginine concentrations as a result of the rapid production of urea from arginine. The enzyme responsible for this converion, arginase, cannot use indospicine as a substrate while canavanine is a poor substrate. Accordingly either analogue has the potential for producing toxic effects in liver, a hypothesis emphasized by the production of heat-labile PEPCK at very low indospicine concentrations. Indospicine produces marked pathological effects in liver when it is fed in the diet, and it leads to death at quite low doses (Hegarty \& Pound, 1970; Christie, Wilson \& Hegarty, 1975).

Maximum response to an analogue will occur when all three situations listed previously are present, i.e. the analogue is present in large amounts, it is a good substrate for protein synthesis and the appropriate normal amino acid is essentially absent. Clearly the arginine analogues indospicine and canavanine closely fit these conditions in their action on liver.

The amino acids we have tested for their effects on protein turnover are analogues to only a few of the normal amino acids. Yet the majority of the analogues used affect protein synthesis, protein degradation, or both processes in one of the cell types. It must be expected that many other compounds related to the twenty normal amino acids will have toxic effects which can be readily assessed in isolated mammalian cells.

\section{REFERENCES}

Allende, C. C. \& Allende, J. E. (1964). J. biol. Chem. 239, 1102.

Ballard, F. J. \& Hanson, R. W. (1969). J. biol. Chem. 244, 5625.

Baum, B. J., Johnson, L. S., Franzblau, C. \& Troxler, R. F. (I975). J. biol. Chem. 250, I464.

Bell, E. A. (1976). FEBS Lett. 64, 29.

Bell, E. A. \& Janzen, D. H. (197I). Nature, Lond, 229, 136.

Christie, G. S., Wilson, M. \& Hegarty, M. P. (I975). J. Path. I17, I95.

Eagle, H. (1959). Science, N.Y. 130, 432.

Fowden, L. (1959). Biochem. J. 71, 643 .

Fowden, L. (1974). Rec. Adv. Phytochem. 8, 95.

Fowden, L., Lewis, D. \& Tristram, H. (1967). Adv. Enzym. 29, 89.

Goldberg, A. L. \& Dice, J. F. (1974). A. Rev. Biochem. 43, 835.

Hegarty, M. P., Court, R. D. \& Thorne, P. M. (1964). Aust. J. agric. Res. 15, 168.

Hegarty, M. P. \& Pound, A. W. (1970). Aust. J. biol. Sci. 23, 831.

Hegarty, M. P., Schinckel, P. G. \& Court, R. D. (1964). Aust. J. agric. Res. 15, I53.

Knowles, S. E., Gunn, J. M., Hanson, R. W. \& Ballard, F. J. (1975). Biochem. J. 146, 595.

Knowles, S. E., Gunn, J. M., Reshef, L., Hanson, R. W. \& Ballard, F. J. (1975). Biochem. J. r46, 585.

Kruse, P. F., White, P. B., Carter, H. A. \& McCoy, T. A. (I959). Cancer Res. r9, I 22.

Lowry, O. H., Rosebrough, N. J., Farr, A. L. \& Randall, R. J. (1951). J. biol. Chem. r93, 265.

Schimke, R. T. (1970). Meth. Enzym. I7A, 313. 